\title{
Analisis Angka Harapan Lama Sekolah di Indonesia Timur Menggunakan Weighted Least Squares Regression
}

\author{
Arifin M. Kahar \\ Prodi Magister Statistika Terapan, Universitas Padjajaran, ipinputera@gmail.com
}

DOI:https://doi.org/10.15642/mantik.2018.4.1.32-41

\begin{abstract}
Abstrak
Indeks Pembangunan Manusia (IPM) merupakan salah satu data dan informasi yang digunakan oleh pemerintah daerah untuk mengukur pencapaian pembangunan manusia dengan sejumlah komponen dasar kualitas hidup yaitu angka harapan hidup yang mewakili dimensi kesehatan, angka harapan lama sekolah (HLS) dan rata-rata lama sekolah (RLS) mewakili dimensi pendidikan, dan rata-rata pengeluaran per kapita disesuaikan yang mewakili dimensi hidup layak. IPM khususnya di wilayah Indonesia Timur pada tiga tahun terakhir terus meningkat namun angkanya selalu berada di bawah angka nasional. Salah satu dimensi yang masih rendah pencapaiannya adalah dimensi pendidikan. HLS merupakan salah satu indikator pada dimensi pendidikan yang masih rendah pencapaiannya. Untuk itu, penelitian ini ingin mengetahui pengaruh persentase penduduk miskin, Produk Domestik Regional Bruto (PDRB) per kapita, angka partisipasi murni (APM) SMP, dan rasio fasilitas pendidikan terhadap HLS di wilayah Indonesia Timur pada 2016. Dengan metode Weighted Least Squares (WLS) diperoleh kesimpulan bahwa keempat variabel prediktor berpengaruh signifikan terhadap HLS di Indonesia Timur.
\end{abstract}

Kata Kunci : Angka Harapan Lama Sekolah, Heteroskedastisitas, Weighted Least Squares

\begin{abstract}
Human Development Index (HDI) is one of the data and information used by the local government to measure the achievement of human development with the basic components of quality of life that is life expectancy that represents health dimension, expected years of schooling (EYS) and mean years of schooling (MYS) represents the educational dimension, and purchasing power parity that represents decent living dimension. HDI especially in eastern Indonesia in the last three years has continued to increase but the figure is always below from the national figure even left behind if compared with West Indonesia. One dimension that is still low achievement is the educational dimension. EYS is one of the indicators on the educational dimension that is still a low achievement. Therefore, this research would like to know the influence of percentage of poor people, Gross Regional Domestic Product (GRDP) per capita, net enrollment rate (NER) of junior high school, and a ratio of educational facilities to EYS in eastern Indonesia. Using Weighted Least Squares (WLS) method concluded that the four predictor variables used were able to influence EYS in Eastern Indonesia.
\end{abstract}

Keywords: Expected Years of Schooling, Heteroscedasticity, Weighted Least Squares 


\section{Pendahuluan}

Secara sederhana pembangunan dapat dimaknai sebagai usaha atau proses untuk melakukan perubahan ke arah yang lebih baik. Pada pelaksanaannya pembangunan bersifat multi dimensi dan memiliki berbagai kompleksitas masalah. Proses pembangunan terjadi di semua aspek kehidupan masyarakat, baik aspek ekonomi, politik, sosial, maupun budaya.

Sejak diberlakukannya otonomi daerah di Indonesia, pemerintah daerah diberikan wewenang untuk mengelola daerahnya masing-masing. Hal tersebut berdampak pada meningkatnya kebutuhan akan data atau informasi yang lebih detail mengenai keadaan suatu daerah. Data tersebut selain berguna untuk mengetahui dan mengevaluasi hasil pembangunan juga digunakan sebagai acuan dalam merumuskan kebijakan pembangunan di tingkat daerah. Indeks Pembangunan Manusia (IPM) merupakan salah satu data dan informasi yang digunakan oleh pemerintah daerah untuk mengukur pencapaian pembangunan manusia dengan sejumlah komponen dasar kualitas hidup. Komponen yang digunakan dalam perhitungan IPM adalah angka harapan hidup yang mewakili dimensi kesehatan, angka harapan lama sekolah (HLS) dan rata-rata lama sekolah (RLS) mewakili dimensi pendidikan, dan rata-rata pengeluaran per kapita yang disesuaikan mewakili capaian pembangunan untuk hidup layak.

Data IPM yang dikeluarkan BPS khususnya di wilayah timur Indonesia pada tiga tahun terakhir terus meningkat namun angkanya selalu berada di bawah angka nasional. Pada 2016, IPM Indonesia sudah mencapai 70,18 namun angka IPM Maluku, Maluku Utara, Papua Barat dan Papua belum mampu menyentuh angka tersebut. Salah satu dimensi penyebab IPM pada keempat provinsi tersebut rendah adalah dimensi pendidikan yang diukur dari HLS dan RLS [1].

Data BPS menunjukkan bahwa HLS dan RLS Maluku dan Maluku Utara sudah berada di atas angka nasional. Akan tetapi,
Papua dan Papua Barat masih jauh tertinggal. Hasil ini memberi gambaran bahwa masih terdapat perbedaan angka yang cukup jauh dengan angka nasional terutama di Papua dan Papua Barat.

Secara nasional, penduduk Indonesia usia tujuh tahun ke atas berpotensi menempuh pendidikan hingga Diploma I pada 2016. Hal ini dapat dilihat dari angka HLS yang mencapai 12,72 tahun $(12,72$ $\approx 13$ tahun $=$ SD 6 tahun + SMP 3 tahun + SMA 3 tahun + Perguruan Tinggi 1 Tahun). Pada tahun yang sama, HLS wilayah timur Indonesia khususnya di Papua Barat mencapai 12,26 tahun. Artinya pada tahun tersebut penduduk usia 7 tahun ke atas di provinsi tersebut berpotensi menempuh pendidikan hingga tamat SMA (12 tahun=SD 6 tahun + SMP 3 tahun + SMA 3 tahun). Sementara HLS di Papua baru mencapai 10,23 tahun, artinya pada tahun tersebut penduduk usia 7 tahun ke atas di provinsi ini berpotensi menempuh pendidikan hingga jenjang SMA kelas I $(10$ tahun $=$ SD 6 tahun + SMP 3 tahun + SMA 1 tahun).

Perbedaan pembangunan pendidikan tampak begitu nyata antara wilayah barat dengan timur Indonesia. Meskipun Maluku dan Maluku Utara memiliki HLS yang sudah berada di atas angka nasional. Akan tetapi keempat provinsi di wilayah timur Indonesia ini masih sangat jauh tertinggal jika dibandingkan dengan wilayah barat Indonesia seperti Daerah Istimewa Yogyakarta.

\section{Tinjauan Pustaka \\ 2.1 Angka Harapan Lama Sekolah}

HLS merupakan salah satu output yang dapat digunakan untuk memotret pemerataan pembangunan pendidikan di Indonesia. Karena HLS mengukur kesempatan pendidikan seorang penduduk di mulai pada usia tujuh tahun. Secara sederhana, HLS dapat didefinisikan sebagai angka partisipasi sekolah menurut umur tunggal. HLS merupakan indikator yang menggambarkan lamanya sekolah (dalam tahun) yang diharapkan akan dirasakan oleh anak pada umur tertentu di masa mendatang. Angka ini diperoleh dengan 
cara membagi banyaknya partisipasi sekolah penduduk pada usia a pada tahun $\mathrm{t}$ dengan jumlah penduduk yang bersekolah pada usia a pada tahun t. Sebagai catatan indikator ini dianggap peka dalam menggambarkan variasi antar provinsi. Menurut United Nation Development Programme (UNDP), HLS dihitung dengan cara sebagai berikut [2]:

Dimana:

$$
H L S_{a}^{t}=\sum_{i=a}^{t} \frac{E_{i}^{t}}{P_{i}^{t}}
$$

$$
\begin{aligned}
& H L S_{a}^{t} \text { : Harapan lama sekolah pada } \\
& \text { usia } a \text { dan pada tahun } t \\
& E_{i}^{t} \quad \text { : Partisipasi sekolah penduduk } \\
& \text { usia } i \text { pada tahun } t \\
& P_{i}^{t} \quad \text { : Populasi penduduk usia } i \\
& \text { yang bersekolah pada tahun } t \\
& i \quad \text { : Usia }(a, a+1, \ldots, n)
\end{aligned}
$$

Salah satu tujuan Sustainable Develompment Goals (SDGs) yaitu tujuan keempat adalah menjamin kualitas pendidikan yang adil dan inklusif serta meningkatkan kesempatan belajar seumur hidup untuk semua. Pada target $4 \mathrm{~b}$, dinyatakan bahwa memastikan semua anak perempuan dan anak laki-laki memiliki akses ke pengembangan anak usia dini yang setara, perawatan, dan pendidikan anak usia dini sehingga mereka siap untuk pendidikan dasar. Pada target ini, diharapkan angka kelulusan baik SD, SMP, maupun SMA ditingkatkan. Secara langsung, ketika target ini dicapai maka angka HLS dan RLS yang merupakan dua indikator penghitungan IPM akan ikut meningkat [3].

Akan tetapi, kondisi saat ini dapat dikatakan bahwa target $4 \mathrm{~b}$ pada SDGs akan sulit tercapai untuk wilayah timur Indonesia dalam waktu dekat. Belum meratanya pembangunan pendidikan di Indonesia menjadi salah satu penyebab target tersebut tidak tercapai.

Menurut Darisandi, beberapa hal yang menjadi penyebab belum meratanya pendidikan di Indonesia diantaranya adalah [4]:

1. Perbedaan tingkat sosial

Pernyataan World Development Report bahwa pendidikan adalah kunci untuk menciptakan, menyebarluaskan pengetahuan. Namun akses terhadap pendidikan tidak tersebar secara merata dan golongan miskin paling sedikit mendapat bagian. Kasus ini dapat ditemukan di Indonesia yang pendidikannya belum merata antara masyarakat miskin dan golongan masyarakat menengah ke atas.

2. Keadaan geografis

Secara geografis, wilayah Indonesia yang cukup luas sebagai negara kepulauan ternyata menjadi salah satu penghambat pemerataan pembangunan pendidikan. Hal tersebut berakibat bahwa pembangunan pendidikan tidak dapat terlaksana dengan optimal khususnya di daerah Indonesia Timur. Ketimpangan pembangunan pendidikan antara satu wilayah dengan wilayah yang lain sangat terlihat sekali, baik secara fisik maupun non fisik.

3. Sebaran sekolah tidak merata

Sebagian besar pendirian lembaga pendidikan masih berada dan berorientasi di wilayah perkotaan, sedangkan minat untuk membangun lembaga pendidikan di daerah pedesaan masih sangat kurang. Kemudian pembangunan sekolah yang hanya terpusat di Wilayah Barat khususnya Pulau Jawa membuat sebaran sekolah menjadi tidak merata. Padahal dengan kebutuhan pendidikan yang sangat besar di Indonesia Timur seharusnya di prioritaskan pembangunan yang cukup besar pula.

\subsection{Ordinary Least Squares (OLS)}

Bentuk umum model regresi linier berganda dengan $\mathrm{k}$ variabel bebas adalah sebagai berikut [5]:

$$
\begin{gathered}
Y_{i}=\beta_{0}+\beta_{1} X_{1}+\beta_{2} X_{2}+\cdots \\
+\beta_{k} X_{k}+\varepsilon_{i}
\end{gathered}
$$

dengan:

- $Y_{i}$ adalah variabel respon untuk pengamatan ke- $i$, untuk $i=1,2, \ldots, n$.

- $\beta_{0}, \beta_{1}, \beta_{2}, \ldots, \beta_{k}$ adalah parameter

- $X_{0}, X_{1}, X_{2}, \ldots, X_{k}$ adalah variabel prediktor

- $\varepsilon_{i}$ adalah sisa (error) untuk pengamatan ke- $i$.

Dalam notasi matriks, persamaan (1) dapat dutulis sebagai berikut:

$$
\boldsymbol{Y}=\boldsymbol{X} \boldsymbol{\beta}+\boldsymbol{\varepsilon}
$$


dimana:

$\boldsymbol{Y}=\left[\begin{array}{c}Y_{1} \\ Y_{2} \\ \vdots \\ Y_{n}\end{array}\right], \boldsymbol{X}=\left[\begin{array}{cccc}X_{11} & X_{12} & \cdots & X_{1 k} \\ X_{21} & X_{22} & \cdots & X_{2 k} \\ \vdots & \vdots & \ddots & \vdots \\ X_{n 1} & X_{n 2} & \cdots & X_{n k}\end{array}\right]$,

$\boldsymbol{\varepsilon}=\left[\begin{array}{c}\varepsilon_{1} \\ \varepsilon_{2} \\ \vdots \\ \varepsilon_{n}\end{array}\right]$

dengan:

- $\boldsymbol{Y}$ adalah vektor variabel tidak bebas berukuran $n \times 1$.

- $\boldsymbol{X}$ adalah matriks variabel bebas berukuran $n \times(k+1)$.

- $\boldsymbol{\beta}$ adalah vektor parameter berukuran (k+1) $x 1$.

- $\varepsilon$ adalah vektor error berukuran $n \times 1$.

Bentuk umum model regresi taksiran adalah sebagai berikut:

$\hat{Y}_{i}=\hat{\beta}_{0}+\hat{\beta}_{1} X_{1}+\hat{\beta}_{2} X_{2}+\cdots \cdot+\hat{\beta}_{k} X_{k}$

\subsection{Deteksi Heteroskedastisitas}

Menurut Gujarati [5] asumsi-asumsi pada model regresi linier berganda adalah sebagai berikut:

a. Model regresinya adalah linier dalam parameter.

b. Nilai rata-rata dari error adalah nol.

c. Variansi dari error adalah konstan (homoskedastitisitas).

d. Tidak terjadi autokorelasi pada error.

e. Tidak terjadi multikolinieritas pada variabel bebas.

f. Error berdistribusi normal.

Salah satu pelanggaran asumsi yang sering terjadi pada model OLS adalah asumsi variansi dari error tidak konstan (heteroskedastisitas). Dampak adanya heteroskedastisitas adalah walaupun estimator OLS masih linier dan tidak bias, tetapi tidak lagi mempunyai variansi yang minimum dan menyebabkan perhitungan standard error metode OLS tidak bisa dipercaya kebenarannya. Selain itu interval estimasi maupun pengujian hipotesis yang didasarkan pada distribusi $\mathrm{t}$ maupun $\mathrm{F}$ tidak bisa lagi dipercaya untuk evaluasi hasil regresi.

Akibat dari dampak heteroskedastisitas tersebut menyebabkan estimator OLS tidak menghasilkan estimator yang Best Linear Unbiased Estimator (BLUE) dan hanya menghasilkan estimator OLS yang linear unbiased estimator (LUE).

Selanjutnya untuk mendeteksi adanya heteroskedastisitas pada model OLS dapat menggunakan uji Goldfeld-Quandt. Berikut adalah tahapan pengujiannya [6]:

a. Asumsi:

- $\mathrm{n} \geq 2(\mathrm{k}) ; \mathrm{k}$ adalah banyaknya variabel bebas.

- Error berdistribusi normal.

b. Hipotesis:

$\mathrm{H}_{0}: \mathrm{e}_{\mathrm{i}}$ Homoskedastisitas

$\mathrm{H}_{1}: \mathrm{e}_{\mathrm{i}}$ Heteroskedastisitas

c. Prosedur:

- Urutkan nilai-nilai $\mathrm{X}_{\mathrm{i}}$

- Untuk $\mathrm{n}$ besar maka hilangkan c pengamatan yang ditengah-tengah sehingga terdapat 2 bagian yang sama masing-masing $1 / 2(n-c)$ bagian nilai $X$ yang kecil dan $1 / 2(n-c)$ bagian nilai $X$ yang besar.

- Dengan OLS taksir secara terpisah setiap bagian kemudian hitung masing-masing residunya $\varepsilon_{\mathrm{i}}$ sehingga diperoleh $\sum \varepsilon_{\mathrm{i}}^{2}$ kecil dan $\sum \varepsilon_{\mathrm{i}}^{2}$ besar.

- Hitung statistik ujinya:

$$
F=\frac{\sum_{i=1}^{n_{2}} \varepsilon_{i B e s a r}^{2}}{\sum_{j=1}^{n_{1}} \varepsilon_{i \text { Kecil }}^{2}} \sim F_{\substack{(1 / 2(n-c)-(k+1), 1 / 2(n-c)-(k+1))}}
$$

Dimana,

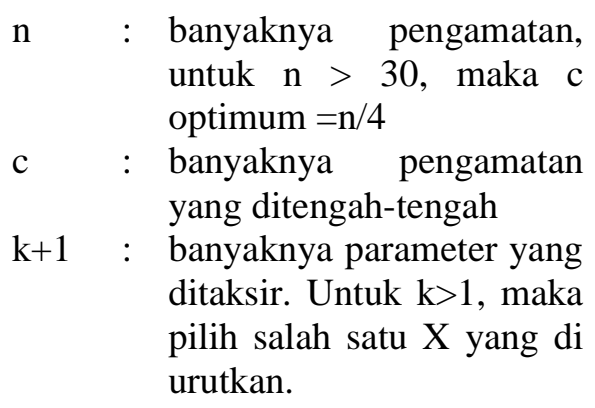

d. Keputusan:

Terdapat homoskedastisitas jika nilai $F$ $\sim 1$, jika $\mathrm{F}_{\text {hitung }}>\mathrm{F}_{\text {tabel }}$ atau $\mathrm{p}$-value $<\alpha$ maka $\mathrm{H}_{0}$ ditolak, artinya terdapat heteroskedastisitas. 


\subsection{Weighted Least Squares (WLS)}

Salah satu cara untuk mengatasi pelanggaran asumsi homoskedastisitas adalah menggunakan metode WLS. Metode ini merupakan salah satu metode penaksiran yang digunakan ketika error tidak saling berkorelasi namun memiliki varians yang sama. Ketika $\sum$ adalah matriks diagonal, maka dapat diinterpretasikan bahwa error tidak saling berkorelasi namun varians error tidak homogen. Jika $\sum=$ diag $\left(\sqrt{1 / W_{i}}, \ldots, \sqrt{1 / W_{n}}\right)$, maka kita dapat meregresikan $\sqrt{\mathrm{w}_{\mathrm{i}}} \mathrm{x}_{i}$ pada $\sqrt{\mathrm{w}_{\mathrm{i}}} \mathrm{y}_{i}$ (kolom satuan pada matriks $\mathbf{X}$ perlu diganti dengan $\left.\sqrt{\mathrm{w}_{\mathrm{i}}}\right)$ [7].

Misalkan: $\mathrm{E}\left(\varepsilon_{\mathrm{i}}^{2}\right)=\sigma_{\mathrm{i}}^{2}$ dan

$\sum_{i=1}^{n} w_{i} \mathrm{e}_{i}^{2}=\sum_{i=1}^{n} w_{i}\left(Y_{i}-\beta_{0}-\beta_{1} X_{i}\right)^{2}$

Maka akan diperoleh taksiran untuk parameter $\beta_{1}$ dan varians $\left(\beta_{1}\right)$ sebagai berikut:

$\hat{\beta}_{1}=\frac{\left(\sum_{i=1}^{n} w_{i}\right)\left(\sum_{i=1}^{n} w_{i} x_{i} y_{i}\right)-\left(\sum_{i=1}^{n} w_{i} x_{i}\right)\left(\sum_{i=1}^{n} w_{i} y_{i}\right)}{\left(\sum_{i=1}^{n} w_{i}\right)\left(\sum_{i=1}^{n} w_{i} x_{i}^{2}\right)-\left(\sum_{i=1}^{n} w_{i} x_{i}\right)^{2}}$

$\operatorname{var}\left(\hat{\beta}_{1}\right)=\frac{\sum_{i=1}^{n} w_{i}}{\left(\sum_{i=1}^{n} w_{i}\right)\left(\sum_{i=1}^{n} w_{i} x_{i}^{2}\right)-\left(\sum_{i=1}^{n} w_{i} x_{i}\right)^{2}}$

dengan: $w_{i}=\frac{1}{\sigma_{i}^{2}}$

Penentuan $W_{i}$ juga dapat dilakukan dengan beberapa cara diantaranya adalah [8]:

- Jika varians error proporsional terhadap variabel respon $\left(\operatorname{var}\left(\varepsilon_{i}\right) \propto Y_{i}\right)$ maka disarankan $W_{i}=\frac{1}{Y_{i}}$

- Jika $Y_{i}$ adalah rata-rata dari $n_{i}$ observasi dengan $\operatorname{var}\left(\mathrm{Y}_{i}\right) \propto \operatorname{var}\left(\varepsilon_{i}\right) \propto \frac{\sigma_{i}^{2}}{n_{i}}$, disarankan $W_{i}=n_{i}$.

- Jika varians error proporsional terhadap prediktor $\quad\left(\operatorname{var}\left(\varepsilon_{i}\right) \propto X_{i}\right)$ maka disarankan $W_{i}=\frac{1}{X_{i}}$.

- Jika varians error proporsional terhadap prediktor kuadrat $\left(\operatorname{var}\left(\varepsilon_{i}\right) \propto X_{i}^{2}\right)$ maka disarankan $W_{i}=\frac{1}{\sqrt{\mathrm{X}_{\mathrm{i}}}}$.

- Jika varians error proporsional terhadap $\left[E\left(Y_{i}\right)\right]^{2}$ maka disarankan $W_{i}=\frac{1}{\widehat{Y}_{l}}$.

\section{Metode Penelitian}

3.1 Sumber Data dan Variabel Penelitian

Penelitian ini menggunakan data sekunder tahun 2016 yang diperoleh dari Badan Pusat Statistik Republik Indonesia (BPS RI) kemudian diolah dengan sofware $R$ seri 3.4.3. Adapun data yang digunakan adalah angka harapan lama sekolah sebagai variabel repon serta variabel prediktornya adalah persentase penduduk miskin $\left(\mathrm{X}_{1}\right)$, PDRB per kapita (dalam juta rupiah, $\mathrm{X}_{2}$ ), APM SMP $\left(X_{3}\right)$ dan rasio fasilitas pendidikan per 10.000 penduduk $\left(\mathrm{X}_{4}\right)$. Unit observasi pada penelitian ini adalah seluruh kabupaten/kota di Indonesia timur.

\subsection{Tahapan Penelitian}

Tahapan penelitian yang dilakukan adalah sebagai berikut:

1. Melakukan uji linearitas dalam parameter,

2. Melakukan pemodelan dengan metode Ordinary Least Squares (OLS),

3. Melakukan uji asumsi klasik (normalitas, homogenitas, dan multikolinearitas),

4. Melakukan pemodelan dengan metode Weighted Least Squares (WLS) untuk mengatasi pelanggaran asumsi homoskedastisitas,

5. Melakukan uji asumsi normalitas dan multikolinearitas untuk model WLS,

6. Melakukan uji parameter model WLS,

7. Analisis pengaruh variabel prediktor terhadap variabel respon.

\section{Hasil dan Pembahasan}

Sebelum melakukan analisis lebih lanjut terlebih dahulu diuji apakah variabel yang digunakan memenuhi asumsi linearitas dalam parameter atau tidak. Asumsi ini dapat menggunakan pendekatan grafis untuk mendeteksi apakah variabel prediktor yang digunakan memiliki hubungan yang linear atau tidak dengan variabel responnya. Berikut adalah bentuk dari scatter plot untuk keempat variabel prediktor dengan variabel respon. 

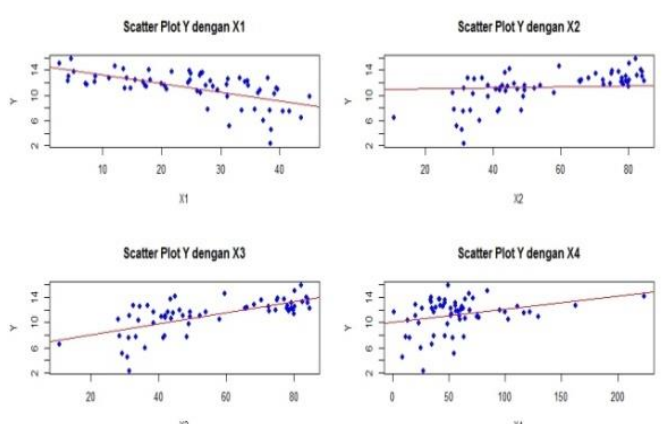

Gambar 1. Scatter Plot variabel respon dengan variabel prediktor

Pada gambar 1 terlihat bahwa keempat variabel prediktor yang akan digunakan di dalam model memiliki hubungan yang linear. Variabel prediktor $\mathrm{X}_{2}, \mathrm{X}_{3}$ dan $\mathrm{X}_{4}$ memiliki hubungan linear yang positif. Artinya apabila semakin besar nilai X maka nilai $\mathrm{Y}$ juga semakin besar. Sebaliknya untuk variabel $\mathrm{X}_{1}$, semakin besar nilai $\mathrm{X}_{1}$ maka nilai $\mathrm{Y}$ akan semakin menurun atau memiliki hubungan linear yang negatif.

\subsection{Pengujian Asumsi Model OLS Normalitas}

Hasil pengujian normalitas menggunakan Uji Shapiro Wilks dengan nilai $p$-value yang diperoleh sebesar 0.113 , lebih besar dari $\alpha=0.05$. Hasil ini memberikan kesimpulan bahwa model OLS berasal dari sampel berdistribusi normal.

\section{Homoskedastisitas}

Melalui uji Goldfeld-Quandt diperoleh nilai $p$-value sebesar 0.000138 , lebih kecil dari $\alpha=0.05$. Dari hasil ini diputuskan bahwa tidak cukup bukti untuk mengatakan varians error adalah homogen sehingga dapat disimpulkan bahwa variansi error pada model adalah tidak konstan atau terdapat heteroskedastisitas.

\section{Multikolinearitas}

Variance Inflation Factor (VIF) yang digunakan sebagai alat deteksi multikolinearitas menunjukkan nilai untuk keempat variabel prediktor sebagai berikut $X_{1}=2,72 ; X_{2}=1,79 ; X_{3}=1,14 ;$ dan $X_{4}=2,51$. Keempat nilai ini lebih kecil dari 10 sehingga dapat disimpulkan bahwa tidak terdapat multikolinearitas pada variabel prediktor.

\subsection{Penanganan Heteroskedastisitas}

Karena model OLS yang terbentuk terdapat heteroskedastisitas, maka langkah selanjutnya adalah mengatasi pelanggaran asumsi tersebut menggunakan metode WLS.

Langkah awal pada metode WLS adalah menentukan pembobot yaitu dengan melihat pola yang ditunjukkan error terhadap variabel bebas. Berdasarkan pola tersebut maka pada penelitian ini akan menggunakan beberapa pembobot diantaranya adalah $1 / \mathrm{X}_{1}, 1 / \sqrt{\mathrm{X}_{2}}, 1 / \mathrm{X}_{3}, 1 / \mathrm{X}_{4}$. Berikut hasil pendeteksian heteroskedastisitas dengan Uji GoldfeldQuandt:

Tabel 1. Hasil Uji Goldfeld-Quandt (GQ) dengan Metode WLS

\begin{tabular}{ccc}
\hline Pembobot & Nilai GQ & p-value \\
\hline$(1)$ & $(2)$ & $(3)$ \\
\hline $1 / \sqrt{\mathrm{X}_{1}}$ & 1.062 & 0.440 \\
\hline $1 / \mathrm{X}_{2}$ & 12.588 & 0.000 \\
\hline $1 / \sqrt{\mathrm{X}_{3}}$ & 10.174 & 0.000 \\
\hline $1 / \mathrm{X}_{4}$ & 20.926 & 0.000 \\
\hline
\end{tabular}

Berdasarkan hasil pada tabel $1 \mathrm{di}$ atas disimpulkan bahwa pembobot $1 / \sqrt{\mathrm{X}_{1}}$ yang dapat memenuhi asumsi homoskedastisitas karena nilai $p$-value lebih besar dari $\alpha=0.05$.

\subsection{Pengujian Asumsi Model WLS Normalitas}

Hasil uji Shapiro Wilks diperoleh nilai W sebesar 0.9794 dan $p$-value sebesar 0.371 . Karena nilai $p$-value lebih besar dari $\alpha=0.05$ maka dapat disimpulkan bahwa model WLS berasal dari sampel yang berdistribusi normal.

\section{Multikolinearitas}

Nilai VIF yang diperoleh untuk model WLS dengan pembobot $1 / \sqrt{\mathrm{X}_{1}}$ adalah $\mathrm{X}_{1}=5.52 ; \mathrm{X}_{2}=1.67 ; \mathrm{X}_{3}=6.28$; dan $X_{4}=5.36$. Keempat nilai ini lebih kecil dari 10 sehingga dapat disimpulkan bahwa 
tidak terdapat multikolinearitas pada variabel prediktor.

\subsection{Pengujian Parameter Model WLS Statistik Uji F}

Statistik uji $\mathrm{F}$ dapat digunakan untuk mengetahui secara serentak seluruh variabel prediktor yang digunakan signifikan di dalam model. Berikut hipotesis dan kriteria penolakannya:

Hipotesis:

$\mathrm{H}_{0}: \beta_{\mathrm{i}}=0$

$\mathrm{H}_{1}$ : minimal ada satu $\beta_{\mathrm{i}} \neq 0$

Keputusan:

$\mathrm{H}_{0}$ ditolak jika $\mathrm{F}_{\text {hitung }}>\mathrm{F}_{\alpha ; 5 ; 58}=2,37$ atau $p$ value $<\alpha$.

Nilai $F_{\text {hitung }}$ yang dihasilkan pada model dengan pembobot $1 / \sqrt{\mathrm{X}_{1}}$ adalah 926.3 dengan $p$-value sebesar 0.000 . Karena nilai $p$-value kurang dari $\alpha=0.05$ maka dapat disimpulkan bahwa secara serentak seluruh variabel prediktor yang digunakan signifikan di dalam model.

Koefisien determinasi ( $R^{2}$ adjusted) terkoreksi yang dihasilkan pada uji serentak model WLS adalah 0.9866. Artinya, sebesar 98,66 persen variansi keragaman data HLS mampu dijelaskan oleh keempat variabel prediktor di dalam model.

\section{Statistik Uji t}

Statistik uji $t$ digunakan untuk mengetahui secara parsial variabel prediktor yang digunakan signifikan atau tidak di dalam model. Berikut hipotesis dan kriteria penolakannya:

Hipotesis:

$\mathrm{H}_{0}: \beta_{\mathrm{i}}=0$ (tidak ada pengaruh peubah $\mathrm{X}_{\mathrm{i}}$ terhadap Y)

$\mathrm{H}_{1}: \beta_{\mathrm{i}} \neq 0$ (ada pengaruh peubah $\mathrm{X}_{\mathrm{i}}$ terhadap $\mathrm{Y})$

Keputusan:

$\mathrm{H}_{0}$ ditolak jika $\left|\mathrm{t}_{\text {hitung }}\right|>t_{\frac{\alpha}{2}}, 58=2,00172$

atau

$p$-value $<\alpha$.

Tabel 2. Estimasi Parameter Regresi

\begin{tabular}{ccccc}
\hline $\begin{array}{c}\text { Vari- } \\
\text { abel }\end{array}$ & $\begin{array}{c}\text { Ko- } \\
\text { efisien }\end{array}$ & SE & thitung & $\begin{array}{c}p \text { - } \\
\text { value }\end{array}$ \\
\hline$(1)$ & $(2)$ & $(3)$ & $(4)$ & $(5)$ \\
\hline $\mathrm{C}$ & 7.646 & 1.396 & 5.477 & 0.000 \\
\hline $\mathrm{X}_{1}$ & -0.052 & 0.022 & -2.416 & 0.019 \\
\hline
\end{tabular}

\begin{tabular}{ccccc}
\hline $\begin{array}{c}\text { Vari- } \\
\text { abel }\end{array}$ & $\begin{array}{c}\text { Ko- } \\
\text { efisien }\end{array}$ & SE & thitung & $\begin{array}{c}p- \\
\text { value }\end{array}$ \\
\hline $\mathrm{X}_{2}$ & 0.007 & 0.003 & 2.064 & 0.044 \\
\hline $\mathrm{X}_{3}$ & 0.065 & 0.014 & 4.719 & 0.000 \\
\hline $\mathrm{X}_{4}$ & 0.016 & 0.006 & 2.676 & 0.009 \\
\hline
\end{tabular}

Hasil pengolahan pada tabel 2 menunjukkan bahwa nilai absolut thitung yang dihasilkan pada model dengan pembobot $1 / \sqrt{\mathrm{X}_{1}}$ untuk semua variabel prediktor lebih besar dari 2,00172 atau $p$ value kurang dari 0.05 sehingga dapat disimpulkan bahwa secara parsial seluruh variabel prediktor yang digunakan signifikan di dalam model.

\subsection{Analisis Pengaruh Variabel Prediktor terhadap HLS}

Hasil penelitian menunjukkan bahwa persentase penduduk miskin, PDRB per kapita, APM SMP dan rasio fasilitas pendidikan per 10.000 penduduk berpengaruh signifikan terhadap angka harapan lama sekolah di Indonesia Timur pada 2016. Model akhir yang terbentuk dengan metode WLS adalah sebagai berikut:

$$
\begin{aligned}
H L S= & 7.646-0.052 \text { Miskin }+ \\
& 0.007 \text { PDRB }+0.065 \text { APM }+ \\
& 0.016 \text { Fasdik }
\end{aligned}
$$

\section{Persentase Penduduk Miskin}

Persamaan (4) memperlihatkan bahwa terdapat hubungan yang negatif antara persentase penduduk miskin $\left(\mathrm{X}_{1}\right)$ dengan HLS. Dapat dilihat bahwa koefisien regresi pada variabel persentase penduduk miskin $\left(\mathrm{X}_{1}\right)$ bernilai negatif. Jika diinterpretasikan, maka setiap peningkatan persentase penduduk miskin sebesar 1 persen akan diikuti dengan penurunan harapan lama sekolah sebesar 0.052 tahun dengan asumsi variabel lain dianggap tidak berubah. Sebaliknya jika terjadi penurunan penduduk miskin sebesar 1 persen akan meningkatkan harapan lama sekolah sebesar 0.052 tahun.

Pada 2016, BPS melaporkan bahwa penduduk miskin yang tidak tamat atau tidak pernah mengenyam pendidikan SD mencapai 54,70 persen di Papua, 23,21 
persen di Papua Barat, 17, 71 persen di Maluku dan 29,73 persen di Maluku Utara. Jika dilihat pada tingkat kabupaten/kota, terdapat 15 kabupaten di Papua memiliki persentase penduduk miskin yang tidak pernah sekolah atau tidak tamat SD lebih dari 40 persen, Papua Barat terdapat 2 kabupaten, Maluku Utara terdapat 1 kabupaten, dan Maluku tidak ada. Kondisi ini memberi gambaran bahwa tingkat pendidikan yang rendah begitu dekat dengan kemiskinan [9].

Selain tingkat pendidikan, BPS juga melaporkan bahwa pada tahun yang sama, belum semua penduduk miskin di Indonesia Timur mengakses pendidikan formal. Angka partisipasi sekolah (APS) penduduk miskin untuk usia 7-12 tahun dan 13-15 tahun pada beberapa kabupaten di Indonesia Timur masih rendah. Di Papua, APS usia 7-12 tahun di Kabupaten Puncak dan Nduga adalah yang terendah yaitu 46,44 persen dan 47,20 persen. Sementara APS usia 13-15 tahun terendah di Kabupaten Puncak (10,03 persen), Kabupaten Deiyai (38,50 persen), Kabupaten Yalimo (40,36 persen), dan Kabupaten Intan Jaya (41,30 persen). APS penduduk miskin usia 7-12 tahun dan 1315 tahun untuk Papua Barat, Maluku dan Maluku Utara telah mencapai lebih dari 70 persen pada seluruh kabupaten/kota. Keadaan ini mengindikasikan bahwa pembangunan pendidikan untuk beberapa kabupaten di Indonesia Timur masih tertinggal.

\section{PDRB per Kapita}

Pada persamaan (4) juga dapat dilihat hubungan yang positif antara variabel PDRB per kapita dengan HLS karena koefisien regresinya bernilai positif. Jika diinterpretasikan, maka setiap peningkatan PDRB per kapita sebesar Rp1.000.000,00 maka akan diikuti dengan peningkatan angka HLS sebesar 0.007 tahun dengan asumsi variabel lain dianggap tidak berubah. Jika PDRB per kapita semakin besar maka HLS juga akan semakin besar dan berlaku juga sebaliknya. Hal ini sejalan dengan data yang dipublikasikan oleh BPS pada 2016 menunjukkan bahwa PDRB per kapita pada beberapa kabupaten di Papua tergolong rendah dan memiliki HLS terendah. Sebaliknya untuk kabupaten/kota yang memiliki PDRB per kapita tinggi cenderung memiliki HLS yang juga tinggi.

\section{APM SMP}

Dari persamaan (4) dapat dilihat bahwa nilai koefisien regresi pada variabel APM SMP $\left(X_{3}\right)$ positif, menunjukkan terdapat hubungan yang positif antara variabel APM SMP dengan HLS. Jika diinterpretasikan, maka setiap peningkatan APM SMP sebesar 1 persen maka akan diikuti dengan peningkatan angka HLS sebesar 0.065 tahun dengan asumsi variabel lain dianggap tidak berubah.

APM SMP adalah variabel yang berhubungan langsung dengan HLS. Hal ini dapat dilihat dari lebih besar pengaruhnya terhadap angka HLS dibandingkan dengan tiga variabel lainnya. APM SMP pada 2016, untuk beberapa kabupaten kota di Papua berbanding lurus dengan angka HLS. Umumnya, kabupaten/kota yang memiliki APM SMP 50 persen ke atas memiliki angka HLS 10 tahun ke atas. Sebaliknya, terdapat beberapa kabupaten yang memiliki APM SMP di bawah 50 persen dan memiliki angka HLS di bawah 10 tahun.

\section{Rasio Fasilitas Pendidikan}

Dari persamaan (4), terdapat hubungan yang positif antara variabel rasio fasilitas pendidikan per 10.000 penduduk $\left(\mathrm{X}_{4}\right)$ dengan HLS, dapat dilihat dari koefisien regresinya yang bernilai positif. Jika diinterpretasikan, maka setiap peningkatan rasio fasilitas pendidikan per 10.000 penduduk $\left(\mathrm{X}_{4}\right)$ sebesar 1 unit maka akan diikuti dengan peningkatan angka harapan lama sekolah sebesar 0.016 tahun dengan asumsi variabel lain dianggap tidak berubah.

Ditinjau dari fasilitas pendidikan, tiga provinsi di Indonesia Timur yaitu Maluku, Maluku Utara, dan Papua Barat memiliki pencapaian yang lebih baik dibandingkan dengan Papua. 
Kabupaten/kota pada ketiga provinsi ini memiliki rasio fasilitas pendidikan yang sebagain besar mencapai 40 unit per 10.000 penduduk atau lebih dan memiliki angka HLS cukup besar. Sedangkan di Papua terdapat sejumlah kabupaten yaitu Intan Jaya, Nduga, Puncak Jaya, Tolikara, Lanny Jaya, Dogiayai, dan Yalimo yang memiliki rasio rasio fasilitas pendidikan kurang dari 40 unit per 10.000 penduduk dan memiliki HLS rendah.

\section{Kesimpulan}

Hasil penelitian ini memberikan kesimpulan bahwa persentase penduduk miskin, PDRB per kapita, APM SMP dan rasio fasilitas pendidikan per 10.000 penduduk berpengaruh signifikan terhadap angka harapan lama sekolah di Indonesia Timur pada 2016. Secara umum, Provinsi Papua menyimpan persoalan yang paling banyak ditinjau dari keempat variabel prediktor dan angka HLS dibandingkan dengan tiga provinsi lainnya. Penyediaan sarana dan prasaran pendidikan yang memadai adalah langkah utama yang harus dilaksanakan noleh pemerintah baik pusat maupun daerah karena fasilitas pendidikan memegang peranan penting dalam meningkatkan angka harapan lama sekolah di Indonesia Timur. Jika fasilitas pendidikan tersedia dengan memadai salah satunya untuk jenjang SMP terutama untuk wilayah-wilayah terisolir dan terpencil di Papua maka perlahan akan memperbaiki APM SMP. Jika AMP SMP terkoreksi naik maka akan meningkatkan Angka harapan lama sekolah.

Langkah selanjutnya adalah menurunkan angka kemiskinan. Penduduk yang hidup di bawah garis kemiskinan akan susah memperoleh pendidikan yang layak. Jika mereka dikeluarkan dari lingkaran kemiskinan maka mereka akan berpeluang untuk memperoleh pendidikan formal yang lebih baik.

\section{Referensi}

[1] Badan Pusat Statistik, diambil dari www.bps.go.id/subject/26/indekspembangunanmanusia.html\#subjekViewTab3, pada tanggal 18 Januari 2018.

[2] Badan Pusat Statistik (BPS) Kabupaten Halmahera Selatan, Indeks Pembangunan Manusia Kabupaten Halmahera Selatan 2015, BPS Kabupaten Halmahera Selatan, Labuha. (2016).

[3] Badan Pusat Statistik (BPS), Indeks Pembangunan Manusia 2016, Badan Pusat Statistik, Jakarta. (2017).

[4] Darisandi, Roby. diambil dari www.academia.edu/7310798/Pemerataan Pendidikan_untuk_Wilayah_Indonesia_Ti mur, pada tanggal 18 Januari 2018.

[5] Gujarati, N.D, Basic Econometrics, 4th edition. McGraw-Hill Companies, Inc, New York. (2003).

[6] Goldfeld, S.M., Quandt, R. E., Some Tests for Homoscedasticity. Journal of the American Statistical Association. 60 (310), (June 1965) 539-547.

[7] Jaya, I.G.N.M, Diktat Kuliah Analisis Regresi, Departemen Statistika Universitas Padjajaran. (2016).

[8] Setyaningsih, Y.D, Noeryanti, Penggunaan Metode Weighted Least Square untuk Mengatasi Masalah Heteroskedastisitas dalam Analisis Regresi (Studi Kasus Pada Data Balita Gizi Buruk Tahun 2014 di Provinsi Jawa Tengah), Jurnal Statistika Industri dan Komputasi (2017), 2(1), 5158.

[9] Badan Pusat Statistik, Data dan Informasi Kemiskinan Kabupaten/Kota 2016, Badan Pusat Statistik, Jakarta. (2017). 


\section{Lampiran}

Tabel 3. IPM Beberapa Provinsi dan Indonesia, 2014-2016

\begin{tabular}{llrrr}
\hline \multirow{2}{*}{$\begin{array}{c}\text { Provinsi/ } \\
\text { Indonesia }\end{array}$} & IPM/ & & & \\
& HLS/ & 2014 & 2015 & 2016 \\
& RLS & & & \\
\hline Maluku & $(2)$ & $(3)$ & $(4)$ & $(5)$ \\
& IPM & 66.74 & 67.05 & 67.60 \\
& HLS & 13.53 & 13.56 & 13.73 \\
Maluku Utara & RLS & 9.15 & 9.16 & 9.27 \\
& IPM & 65.18 & 65.91 & 66.63 \\
& HLS & 12.72 & 13.10 & 13.45 \\
\hline Papua Barat & RLS & 8.34 & 8.37 & 8.52 \\
& IPM & 61.28 & 61.73 & 62.21 \\
& HLS & 11.87 & 12.06 & 12.26 \\
\hline Papua & RLS & 6.96 & 7.01 & 7.06 \\
& IPM & 56.75 & 57.25 & 58.05 \\
& HLS & 9.94 & 9.95 & 10.23 \\
& RLS & 5.76 & 5.99 & 6.15 \\
\hline DIY & IPM & 76.81 & 77.59 & 78.38 \\
& HLS & 14.85 & 15.03 & 15.23 \\
& RLS & 8.84 & 9.00 & 9.12 \\
\hline Indonesia & IPM & 68.90 & 69.55 & 70.18 \\
& HLS & 12.39 & 12.55 & 12.72 \\
& RLS & 7.73 & 7.84 & 7.95 \\
\hline
\end{tabular}

